\title{
Arginine-Glycine-Aspartic Acid- and Fibrinogen $\gamma$-Chain Carboxyterminal Peptides Inhibit Platelet Adherence to Arterial Subendothelium at High Wall Shear Rates \\ An Effect Dissociable from Interference with Adhesive Protein Binding
}

Jeffry B. Lawrence, Wendy S. Kramer, Laurie P. McKeown, Sybil B. Williams, and Harvey R. Gralnick

Hematology Service, Clinical Pathology Department, National Institutes of Health Clinical Center, Bethesda, Maryland 20892; and

Department of Pathology, Medical College of Virginia, Virginia Commonwealth University, Richmond, Virginia 23298

\begin{abstract}
Arg-Gly-Asp (RGD)- and fibrinogen $\gamma$-chain carboxyterminal (GQQHHLGGAKQAGDV) peptides inhibit fibrinogen, fibronectin (Fn), vitronectin, and von Willebrand factor (vWF) binding to the platelet glycoprotein IIb-IIIa complex (GP IIbIIIa). GP IIb-IIIa, vWF, and Fn are essential for normal platelet adherence to subendothelium. We added peptides to normal citrated whole blood before perfusion over human umbilical artery subendothelium and evaluated platelet adherence morphometrically at high $\left(2,600 \mathrm{~s}^{-1}\right)$ and low $\left(800 \mathrm{~s}^{-1}\right)$ wall shear rates. We also examined the effects of the peptides on platelet adhesion to collagen in a static system. At the high wall shear rate, RGDS and GQQHHLGGAKQAGDV caused dose-dependent reduction in the surface coverage with spread and adherent platelets. Amino acid transposition and conservative substitutions of RGD peptides and the AGDV peptide significantly inhibited platelet adherence at $2,600 \mathrm{~s}^{-1}$. By contrast, the modified RGD peptides and AGDV do not affect adhesive protein binding to platelets. None of the native or modified RGD- or fibrinogen $\gamma$-chain peptides significantly inhibited either platelet adherence to subendothelium at $800 \mathrm{~s}^{-1}$ or platelet adhesion to collagen. Our findings demonstrate that peptides that interfere with adhesive protein binding to GP IIb-IIIa inhibit platelet adherence to vascular subendothelium with flowing blood only at high wall shear rates. Platelet adherence to subendothelium at high wall shear rates appears to be mediated by different recognition specificities from those required for fluid-phase adhesive protein binding or static platelet adhesion. (J. Clin. Invest. 1990. 86:1715-1722.) Key words: von Willebrand factor • platelet adhesion • collagen
\end{abstract}

\section{Introduction}

The plasma adhesive proteins fibrinogen $(\mathrm{Fg}),{ }^{1}$ fibronectin (Fn), von Willebrand factor (vWF), and vitronectin (Vn) each

A preliminary report of this study was presented at the 29th Annual Meeting of the American Society of Hematology, 5-8 December 1987, Washington, DC and has been published in abstract form (1987. Blood. 70[Suppl. 1]:353a).

Address reprint requests to Dr. Gralnick, Hematology Service, CPD, NIH Clinical Center, Building 10, Room 2C390, Bethesda, MD 20892.

Received for publication 22 December 1988 and in revised form 20 June 1990.

1. Abbreviations used in this paper: $\mathrm{Fg}$, fibrinogen; $\mathrm{Fn}$, fibronectin; GP IIb-IIIa, platelet glycoprotein IIb-IIIa complex; PRP, platelet-rich

The Journal of Clinical Investigation, Inc.

Volume 86, November 1990, 1715-1722 contain an Arg-Gly-Asp (RGD) sequence (1-5). Natural and synthetic RGD-containing peptides have been shown to inhibit Fg, Fn, vWF, and Vn binding to the platelet glycoprotein IIb-IIIa complex (GP IIb-IIIa) in a competitive and reversible manner (6-11). Similarly, dodeca- and pentadecapeptides (Gly-Gln-Gln-His-His-Leu-Gly-Gly-Ala-Lys-Gln-Ala-GlyAsp-Val) (GQQHHLGGAKQAGDV) of the carboxyl terminus of the $\mathrm{Fg} \gamma$-chain inhibit $\mathrm{Fg}, \mathrm{Fn}$, and vWF binding to platelets (11-13). Both RGD- and $\mathrm{Fg} \gamma$-chain peptides have been shown to alter the conformation of purified GP IIb-IIIa (14). Haverstick et al. (9), using a static system, showed that platelet adhesion to $\mathrm{Fn}, \mathrm{Fg}$, and vWF substrates was inhibited by RGD-containing peptides (9). Amino acid transposition or conservative substitutions led to a loss of the peptides' ability to inhibit both adhesive protein binding to platelets and platelet adhesion (6, 8-11). It was also found that the terminal tetrapeptide of the Fg $\gamma$-chain (AGDV) lacks the inhibitory activity of the dodeca- or pentadecapeptide $(8,11)$.

We and others have demonstrated that GP IIb-IIIa plays a role in platelet adherence to subendothelium in flowing blood, $(15,16)$ and vWF and Fn are required for normal platelet adherence $(17,18)$. To examine the effect of RGD- and Fg $\gamma$-chain peptides on platelet adherence to human arterial subendothelium with flowing blood, we have used the technique of Baumgartner and Muggli (19) with normal citrated whole blood to which the native, substituted, or transposed peptides were added. We compared platelet adherence to human arterial subendothelium at a high $\left(2,600 \mathrm{~s}^{-1}\right)$ and low $\left(800 \mathrm{~s}^{-1}\right)$ wall shear rate. We also tested the peptides' effects upon platelet adhesion to collagen in a static system. These experiments were performed to define whether shear-dependent alterations in GP IIb-IIIa-mediated platelet adherence could be identified.

\section{Methods}

Perfusion procedure and morphologic evaluation. Human umbilical arteries were dissected free from umbilical cords obtained immediately after birth. The arterial segments were everted and de-endothelialized by brief exposure to air and further prepared as previously described (15). For perfusion experiments, the arterial segments were placed in an annular perfusion chamber similar to those developed by Baumgartner and Muggli (19). The chamber contained a rod on which the everted vascular segments were mounted such that the blood entering

plasma; RCD, Ringer's citrate buffer with dextrose; Vn, vitronectin; vWF, von Willebrand factor. Additionally, amino acids are encoded according to the following system: A, alanine; R, arginine; D, aspartic acid; C, cysteine; E, glutamic acid; Q, glutamine; G, glycine; H, histidine; $L$, leucine; $K$, lysine; $M$, methionine; $F$, phenylalanine; $S$, serine; $\mathrm{T}$, threonine; $\mathrm{V}$, valine. 
the chamber flowed through the annular space between the subendothelial surface and the chamber wall, thereby exposing the subendothelium to platelets. The perfusion conditions and rheologic parameters were as previously described (15), and the perfusions were performed at $37^{\circ} \mathrm{C}$ for $5 \mathrm{~min}$ at a flow rate of either $300 \mathrm{ml} / \mathrm{min}$, producing a wall shear rate of $2,600 \mathrm{~s}^{-1}$, or $90 \mathrm{ml} / \mathrm{min}$, leading to a wall shear rate of $800 \mathrm{~s} \mathrm{~s}^{-1}$. The wall shear rates were calculated according to Turitto and Baumgartner (20). The higher wall shear rate closely approximates conditions physiologically present in the microvasculature, or in partially occluded arteries, whereas $800 \mathrm{~s}^{-1}$ is similar to rheologic parameters present in large arteries (21).

The donors were laboratory personnel who had no bleeding history and were not receiving medications that interfered with platelet function. As measured by an electronic counting device (model S Plus, Coulter Electronics, Inc., Hialeah, FL), the mean pre-perfusion values (and ranges) were as follows: hematocrit, $40.1 \%(35.7 \%-45.5 \%)$ and

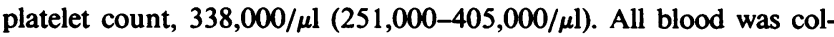
lected into sodium citrate (final whole-blood concentration 10.88 $\mathrm{mM}$ ). A portion of the citrated blood drawn from each donor was used in its native state for control perfusions, whereas synthetic peptides were added to other aliquots of the sample. Each peptide was incubated with the blood for $15 \mathrm{~min}$ at $37^{\circ} \mathrm{C}$, and the control perfusates were also incubated for $15 \mathrm{~min}$ at $37^{\circ} \mathrm{C}$, before perfusions.

After a perfusion experiment, the arterial segment was washed, fixed, sectioned, histologically processed, and embedded in epoxy resin, as previously described (15). Each $0.8-\mu \mathrm{m}$ section was evaluated morphometrically by light microscopy by a single individual who was unaware of the experimental or control group to which it corresponded. The morphometric parameters employed were those of Baumgartner and Muggli (19). The platelet-surface interaction was categorized as either $\mathrm{C}$, contact platelets attached but not spread along the surface, or S, platelets spread along the subendothelium. The latter category may include spread platelets with superimposed platelet thrombi, which are defined as collections of platelets extending $5 \mu \mathrm{m}$ or more in height above the subendothelial surface. Total platelet adherence was defined as $\mathrm{C}+\mathrm{S}$, and each parameter was expressed as a percentage of the total number of points counted $(\sim 1,500)$ per vessel segment. Values are expressed as the mean \pm SEM. Student's $t$ test was used to evaluate the significance of differences between mean values (22). Differences were considered statistically significant if $P<0.05$.

Evaluation of $v W F$ binding to thrombin-stimulated platelets. Platelets were separated from whole blood by centrifugation through a discontinuous arabinogalactan gradient as previously described (11). vWF was purified from normal cryoprecipitate by gel chromatography on Sepharose 4B as described (11). It was radioiodinated with ${ }^{125}$ I by the immobilized lactoperoxidase method (11). The platelets were activated by $0.1 \mathrm{U} / \mathrm{ml}$ thrombin, the thrombin was neutralized by a twofold excess of hirudin, and the radiolabeled vWF was incubated with platelets in the presence of various concentrations of RGD- or Fg $\gamma$-chain peptides for $30 \mathrm{~min}$ at $24^{\circ} \mathrm{C}$, as described (11). The peptides employed in these studies were of the same lot numbers as those used in perfusion experiments. Bound radiolabeled vWF was separated from the free vWF by centrifugation through a $10 \%$ arabinogalactan gradient for 3 min in a Microfuge (Beckman Instruments, Inc., Fullerton, CA) at $12,000 \mathrm{~g}$. The tips of the centrifuge tubes were cut off and counted for ${ }^{125} I$ in a $\gamma$-counter. Nonspecific binding to platelets was determined in the presence of a 100 -fold excess of unlabeled VWF, and represented $<4 \%$ of the total vWF bound. The concentration of each peptide which inhibited $50 \%$ of the control vWF binding, i.e., the $\mathrm{IC}_{50}$, was determined for each peptide.

Preparation of monomeric type I collagen. Type I collagen was isolated from commercial crude preparations of calf skin acid-soluble type I collagen (Sigma Chemical Co., St. Louis, MO) by extraction in $0.5 \mathrm{~mol} /$ liter acetic acid at $4^{\circ} \mathrm{C}$. The extracted material was precipitated by $4 \% \mathrm{NaCl}$, and was redissolved in $0.5 \mathrm{~mol} / \mathrm{liter}$ acetic acid at $4^{\circ} \mathrm{C}$. It was dialyzed for $24 \mathrm{~h}$ against $0.02 \mathrm{~mol} /$ liter sodium phosphate, $\mathrm{pH} 9.0$, until the $\mathrm{pH}$ of the retained material was $>7.0$. The precipitate was then collected by centrifugation at $4^{\circ} \mathrm{C}$ for $30 \mathrm{~min}$ at $7,500 \mathrm{~g}$, redissolved in $0.1 \mathrm{~mol} /$ liter acetic acid, and dialyzed against $0.02 \mathrm{~mol} /$ liter sodium phosphate buffer, $\mathrm{pH}$ 9.0. The collagen solution was lyophilized and frozen at $-70^{\circ} \mathrm{C}$ until used.

Before use, the lyophilized collagen was dissolved in $10 \mathrm{ml}$ of 5.0 mmol/liter acetic acid by gentle mixing overnight at $4^{\circ} \mathrm{C}$. It was centrifuged at $100,000 \mathrm{~g}$ for $1 \mathrm{~h}$ at $4^{\circ} \mathrm{C}$. This preparation was stable at $4^{\circ} \mathrm{C}$ for several weeks (23).

Plate preparation. Immulon No. 2 Removawells (Dynatech, Inc., Chantilly VA) were coated with $50 \mu \mathrm{l}$ of collagen diluted in $5.0 \mathrm{mmol} /$ liter acetic acid to a final concentration of $5 \mu \mathrm{g}$ per well. Plates were incubated in a humidity chamber at $4^{\circ} \mathrm{C}$ overnight or for $3 \mathrm{~h}$ at $24^{\circ} \mathrm{C}$ The collagen was removed by gentle aspiration, and the wells were blocked with $50 \mathrm{mmol} /$ liter Tris- $\mathrm{HCl}$ which contained $5 \mathrm{mmol} / \mathrm{liter}$ $\mathrm{CaCl}_{2}, 1 \%$ bovine serum albumin (BSA), $0.1 \mathrm{mmol} /$ liter phenylmethylsulfonyl fluoride, $0.02 \% \mathrm{NaN}_{3}, \mathrm{pH} 7.8$, for $30-60 \mathrm{~min}$ at $24^{\circ} \mathrm{C}$.

The blocking buffer was aspirated, and the wells were washed three times in $50 \mathrm{mmol} /$ liter Tris- $\mathrm{HCl}$ containing $140 \mathrm{mmol} / \mathrm{liter} \mathrm{NaCl}, 5$ $\mathrm{mmol} / \mathrm{liter}$ glucose, $2 \mathrm{mmol} / \mathrm{liter} \mathrm{MgCl}_{2}, 5 \mathrm{mg} / \mathrm{ml} \mathrm{BSA}$, and $20 \mathrm{ng} / \mathrm{ml}$ prostaglandin $\mathrm{E}_{1}\left(\mathrm{PGE}_{1}\right)$.

Platelet preparation. Blood was drawn from normal donors using a two-syringe technique with a 19-gauge infusion set and polypropylene syringes. The first syringe containing $3-5 \mathrm{ml}$ of blood was discarded. 10 $\mathrm{ml}$ of blood was drawn into a second syringe containing $1.4 \mathrm{ml}$ of acid citrate dextrose-A anticoagulant, $\mathrm{pH}$ 5.1. It was gently mixed and transferred to a polypropylene tube.

Platelet-rich plasma (PRP) was prepared by centrifugation at $24^{\circ} \mathrm{C}$ for $3 \mathrm{~min}$ at $750 \mathrm{~g}$. The PRP was removed and divided into two equal portions in polypropylene tubes. Each of the two tubes of PRP was diluted to $12 \mathrm{ml}$ with Ringer's citrate buffer containing glucose and $\mathrm{PGE}_{1}$ (RCD-PGE $171.9 \mathrm{mmol} / \mathrm{liter} \mathrm{NaCl}, 0.7 \mathrm{mmol} /$ liter $\mathrm{KCl}, 0.6$ $\mathrm{mmol} /$ liter $\mathrm{CaCl}_{2}, 0.8 \mathrm{mmol} / \mathrm{liter} \mathrm{NaHCO}_{3}, 20.0 \mathrm{mmol} / \mathrm{liter}$ trisodium citrate dihydrate, $27.8 \mathrm{mmol} /$ liter glucose, $43 \mathrm{ng} / \mathrm{ml} \mathrm{PGE}_{1}, \mathrm{pH}$ 6.5) and was centrifuged at $24^{\circ} \mathrm{C}$ for $12 \mathrm{~min}$ at $1,100 \mathrm{~g}$. The wash was discarded and the platelet pellets were resuspended in $500 \mu \mathrm{l}$ of RCD$\mathrm{PGE}_{1}$, using a 200- $\mu$ l pipette (Rainin Instrument Co., Inc., Woburn, MA). Each of the two tubes was diluted to $12 \mathrm{ml}$ with RCD-PGE 1 and was centrifuged at $24^{\circ} \mathrm{C}$ for $12 \mathrm{~min}$ at $1,100 \mathrm{~g}$

After centrifugation, the wash was discarded and the platelets were resuspended in $500 \mu \mathrm{l}$ of RCD without $\mathrm{PGE}_{1}$. The two tubes of platelets were pooled, and an additional 1-2 $\mathrm{ml}$ of $R C D$ without $P G_{1}$ was added.

Labeling and platelet adhesion assay. Platelets were labeled by the addition of 300-400 $\mu \mathrm{Ci}$ of [ $\left.{ }^{111} \mathrm{In}\right]$ oxyquinoline (Amersham Corp. Arlington Heights, IL). After incubation at $24^{\circ} \mathrm{C}$ for $15-30 \mathrm{~min}$, unbound "11'In was removed by diluting the platelet suspension to $12 \mathrm{ml}$ with Hepes buffer with $\mathrm{PGE}_{1}(137 \mathrm{mmol} / \mathrm{liter} \mathrm{NaCl}, 2.7 \mathrm{mmol} / \mathrm{liter}$ $\mathrm{KCl}, 4 \mathrm{mmol} / \mathrm{liter} \mathrm{MgCl}_{2}-6 \mathrm{H}_{2} \mathrm{O}, 3.75 \mathrm{mmol} / \mathrm{liter} \mathrm{NaH}_{2} \mathrm{PO}_{4}, 3.8$ mmol/liter hepes, $43 \mathrm{ng} / \mathrm{ml} \mathrm{PGE}_{1}, 0.35 \% \mathrm{BSA}, 5.56 \mathrm{mmol} / \mathrm{liter}$ glucose, $\mathrm{pH} 7.35$ ), and centrifuging them at $24^{\circ} \mathrm{C}$ for $12 \mathrm{~min}$ at $1,100 \mathrm{~g}$. After centrifugation, the labeled platelets were resuspended in Hepes buffer without $\mathrm{PGE}_{1}$. They were counted using a Cellozone cell counter (Particle Data, Inc., Elmhurst, IL).

Equal volumes of platelet suspension and peptide diluted in saline $(0.145 \mathrm{~mol} /$ liter $\mathrm{NaCl})$ were incubated for $20 \mathrm{~min}$ at $24^{\circ} \mathrm{C}$ in 12 $\times 75-\mathrm{mm}$ polystyrene tubes. $50 \mu \mathrm{l}$ of the platelet-peptide or plateletsaline mixture was added to each collagen-coated well. The final platelet concentration was $5 \times 10^{5}$ platelets per well. Control wells included blank, $1 \%$ BSA-, and poly-L-lysine ( $1 \mathrm{mg} / 100 \mathrm{ml}$ in PBS)-coated wells. Minimal platelet binding was observed to blank wells or wells to which $1 \%$ BSA was added, and maximal binding was observed to poly-L-lysine-coated wells. After incubation for $1 \mathrm{~h}$ at $24^{\circ} \mathrm{C}$, the wells were washed three times with $50 \mathrm{mmol} /$ liter Tris- $\mathrm{HCl}$ buffer containing 140 $\mathrm{mmol} /$ liter $\mathrm{NaCl}, 5 \mathrm{mmol} /$ liter glucose, $2 \mathrm{mmol} /$ liter $\mathrm{MgCl}_{2}, 5 \mathrm{mg} / \mathrm{ml}$ BSA, $20 \mathrm{ng} / \mathrm{ml} \mathrm{PGE}_{1}, \mathrm{pH} 7.6$, using an Eppendorf repeater pipette (Brinkmann Instruments, Inc., Westbury, NY) to dispense $100 \mu \mathrm{l}$ of wash buffer into each well, and a digital multichannels pipette (Flow Laboratories, Elflab, Finland) to aspirate from the wells.

The wells were transferred to counting tubes and were counted for $1 \mathrm{~min}$ in a $\gamma$ counter (Tm Analytic, Elk Grove Village, IL).

Peptide characterization. The peptides used were synthesized by 
Bachem Fine Chemicals, Torrance, CA (GQQHHLGGAKQAGDV, VGSE, LG, MFM) or Peninsula Laboratories, Inc., Belmont, CA (all other peptides). The peptides were homogenous by high-performance liquid and thin-layer chromatography, and the amino acid analysis of each peptide was consistent with its predicted composition (assays performed by the suppliers). Each peptide was dissolved in distilled, deionized water at a concentration of $1.25-5 \mathrm{mg} / \mathrm{ml}$ immediately before being added to citrated whole blood. The volume of dissolved peptide added to the whole blood was $<5 \%$ of the whole-blood volume in all experiments (i.e., $100-1,100 \mu \mathrm{l}$ of peptide added to the $25-\mathrm{ml}$ blood perfusate). When $1,100 \mu$ l of saline (PBS: $138 \mathrm{mmol} /$ liter $\mathrm{NaCl}$, $8 \mathrm{mmol} /$ liter $\mathrm{Na}_{2} \mathrm{HPO}_{4}, 0.495 \mathrm{mmol} /$ liter $\mathrm{MgCl}_{2}, 1.47 \mathrm{mmol} /$ liter $\mathrm{KH}_{2} \mathrm{PO}_{4}, 3.23 \mathrm{mmol} /$ liter $\mathrm{KCl}, 0.91 \mathrm{mmol} /$ liter $\mathrm{CaCl}_{2}$ ) was added to perfusates, the platelet-vascular interaction was unchanged, compared with controls (wall shear rate $=2,600 \mathrm{~s}^{-1} ; n=4 ; \mathrm{C}+\mathrm{S}=52.2 \pm 3.0$ vs. $55.4 \pm 3.0$ ). When $1,100 \mu \mathrm{l}$ of distilled, deionized water was added to the

Table I. Platelet Adherence to Human Arterial Subendothelium: Effect of Native and Modified Arg-Gly-Asp-and Fibrinogen $\gamma$-Chain Carboxyterminal Peptides at High Wall Shear Rate $\left(2,600 \mathrm{~s}^{-1}\right)$

\begin{tabular}{lccc}
\hline \multicolumn{1}{c}{ Peptide (n) } & $\begin{array}{c}\text { Contact } \\
\text { (C) }\end{array}$ & Spread (S) & $\begin{array}{c}\text { Total } \\
\text { platelet } \\
\text { adherence } \\
\text { (C+S) }\end{array}$ \\
\hline Controls (25) & $\%$ & $\%$ & \\
VGSE (5) & $1.5 \pm 0.2$ & $53.9 \pm 3.0$ & $55.4 \pm 3.0$ \\
LG (6) & $1.6 \pm 0.3$ & $50.3 \pm 7.1$ & $51.9 \pm 6.9$ \\
MFM (3) & $1.8 \pm 0.1$ & $49.9 \pm 4.7$ & $51.6 \pm 4.8$ \\
RGDS (6) & $1.6 \pm 0.2$ & $51.5 \pm 10.0$ & $53.0 \pm 10.1$ \\
GRGDS (4) & $0.8 \pm 0.2^{*}$ & $19.8 \pm 4.1^{\prime \prime}$ & $20.6 \pm 4.1^{\prime \prime}$ \\
RGDSPASSKP (4) & $1.7 \pm 0.4$ & $26.6 \pm 5.6^{\S}$ & $28.3 \pm 5.5^{\S}$ \\
RGDT (4) & $0.7 \pm 0.2$ & $35.4 \pm 6.6^{\ddagger}$ & $36.2 \pm 6.5^{\ddagger}$ \\
RGDC (4) & $1.2 \pm 0.2$ & $26.4 \pm 3.9^{\S}$ & $27.6 \pm 3.8^{\S}$ \\
RGES (5) & $1.0 \pm 0.2$ & $36.3 \pm 3.2^{\ddagger}$ & $37.3 \pm 3.4^{\ddagger}$ \\
GRADSP (4) & $1.0 \pm 0.1$ & $29.4 \pm 4.0^{\S}$ & $30.3 \pm 4.0^{\S}$ \\
RFDS (4) & $1.1 \pm 0.3$ & $33.6 \pm 4.2^{\ddagger}$ & $34.6 \pm 4.5^{\ddagger}$ \\
KGDS (4) & $1.2 \pm 0.2$ & $35.1 \pm 3.5^{\ddagger}$ & $36.3 \pm 3.6^{\ddagger}$ \\
REDV (4) & $1.5 \pm 0.1$ & $40.3 \pm 6.3^{*}$ & $41.7 \pm 6.4^{*}$ \\
SDGR (5) & $0.8 \pm 0.1$ & $24.8 \pm 5.0^{\prime \prime}$ & $25.6 \pm 5.0^{\prime \prime}$ \\
SDGRG (5) & $1.4 \pm 0.1$ & $39.8 \pm 4.4^{*}$ & $41.2 \pm 4.4^{\ddagger}$ \\
GQQHHLGGAKQAGDV (6) & $0.5 \pm 0.2^{\S}$ & $33.7 \pm 3.8^{\S}$ & $34.2 \pm 4.0^{\S}$ \\
AGDV (6) & $0.9 \pm 0.2$ & $33.7 \pm 5.0^{\S}$ & $34.6 \pm 5.1^{\S}$ \\
& & & \\
\hline & $0.8 \pm 0.2^{*}$ & $23.5 \pm 2.4^{\prime \prime}$ & $24.2 \pm 2.5^{\prime \prime}$ \\
& & &
\end{tabular}

Segments of de-endothelialized human umbilical artery subendothelium were perfused with citrated whole blood from nine normal donors in an annular perfusion chamber at $37^{\circ} \mathrm{C}$ for $5 \mathrm{~min}$ (wall shear rate $=2,600 \mathrm{~s}^{-1}$ ). For the experiments performed on a typical day, a single $150-\mathrm{ml}$ sample of citrated whole blood was obtained by phlebotomy from a normal donor. The control experiments represent perfusion of a $25-\mathrm{ml}$ aliquot of 25 blood samples without any added peptide. To other 25 -ml aliquots of each sample, $50 \mu \mathrm{mol} /$ liter of the designated peptide was added. Light microscopic morphometry defined the percent subendothelial surface coverage with contact platelets $(C)$, spread platelets (S), and total platelet adherence $(C+S)$. The number of perfusions performed in each experimental and control group is indicated in parentheses, and the results are expressed as the mean \pm SEM. Statistically significant differences between values obtained with individual peptides and the combined results from the 25 control perfusions are expressed as follows: ${ }^{*} P<0.05 ;{ }^{\ddagger} P<0.025 ;{ }^{8} P<0.005 ;{ }^{\|} P<0.0005$. perfusates, platelet adherence was also unchanged, compared with simultaneously run controls to which nothing was added $(n=3 ; \mathrm{C}+\mathrm{S}$ $=43.8 \pm 3.9$ vs. $42.0 \pm 7.1$ )

\section{Results}

Inhibition of platelet adherence by peptides containing the $R G D S$ sequence at high wall shear rate $\left(2,600 \mathrm{~s}^{-1}\right)$. Control perfusions with citrated whole blood from normal donors gave values for total platelet adherence $(C+S)$ approximating 55\% coverage of the subendothelial surface (Table I and Fig. 1). Platelet thrombi occupied $0.9 \pm 0.2 \%$ of the surface. When a control peptide, either Val-Gly-Ser-Glu (VGSE), Leu-Gly (LG), or Met-Phe-Met (MFM), was added to the blood, each of the parameters of platelet adherence was unchanged (Table I). However, RGDS caused dose-dependent reduction of surface coverage with spread platelets (S) and $\mathrm{C}+\mathrm{S}$, as well as a small but statistically significant reduction in surface coverage with contact platelets (C) (Table I and Fig. 1). When longer peptides containing the RGDS sequence were used, $S$ and $C+S$ were also significantly inhibited (Table I). However, GRGDS and RGDSPASSKP were somewhat less potent than the tetrapeptide (Tables I and II). Perfusions with 150 and $250 \mu \mathrm{mol} /$ liter GRGDS gave values for C $+\mathrm{S}$ of $18.9 \%$ and $22.2 \%$, respectively. The values for subendothelial coverage with platelet thrombi were not significantly different from the controls with any of these peptides.

Effect of amino acid substitution and transposition on $R G D$-peptide inhibitory properties at high wall shear rate $\left(2,600 \mathrm{~s}^{-1}\right)$. Conservative amino acid substitution of threonine for serine in the fourth position (RGDT) did not significantly impair the peptide's capacity to inhibit $S$ and $C+S$ at a wall shear rate of 2,600 s $\mathrm{s}^{-1}$ (Table I). Similarly, substitution with cysteine in the fourth position (RGDC) produced a peptide that retained the ability to interfere with platelet adherence, although at $50 \mu \mathrm{mol} / \mathrm{liter}$ it caused a $33 \%$ reduction in $\mathrm{C}+\mathrm{S}$, compared with the $63 \%$ reduction produced by RGDS (Table I).

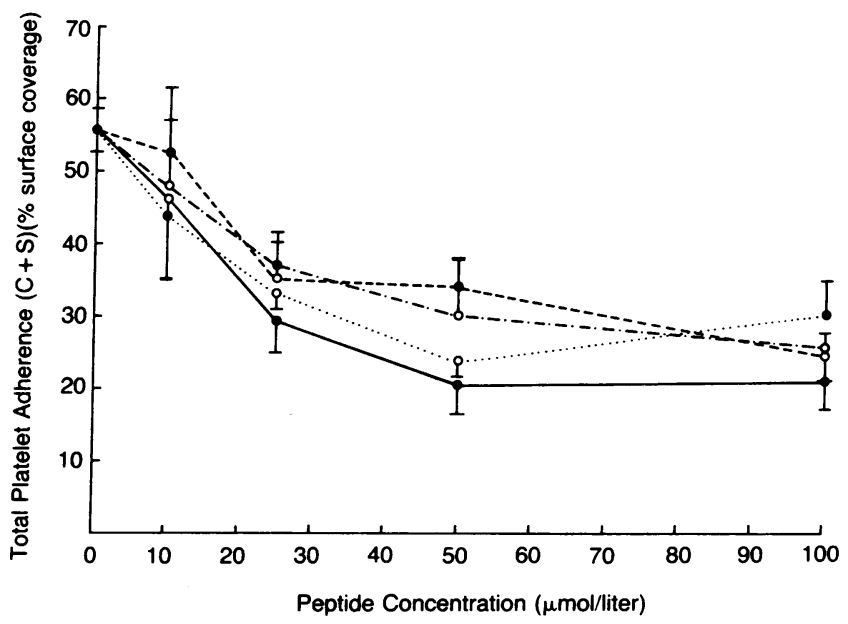

Figure 1. Inhibition of platelet adherence to arterial subendothelium by RGDS and the fibrinogen $\gamma$-chain carboxyterminal pentadecapeptide. Perfusions were performed as described in the legend to Table I with RGDS (-), GQQHHLGGAKQAGDV (-- - - ), SDGRG $(\cdot \cdots \cdot)$, or RGES $(-\cdot-\cdot-\cdot-\cdot)$ added to citrated whole blood at the indicated concentrations. Bars indicate \pm SEM. 
Table II. Structure-functional Relationships for the Inhibition of Platelet Adherence to Subendothelium at High Wall Shear Rate $\left(2,600 \mathrm{~s}^{-1}\right)$ and $v W F$ Binding to Thrombin-stimulated Platelets by Arg-Gly-Asp-and Fibrinogen $\gamma$-Chain Carboxyterminal Peptides

\begin{tabular}{lcc}
\hline \multicolumn{1}{c}{ Peptide } & $\begin{array}{c}\text { Maximal inhibition of } \\
\text { platelet adherence }\end{array}$ & $\begin{array}{c}\text { IC }_{\text {so }} \text { for vWF binding } \\
\text { to platelets }\end{array}$ \\
\hline & $\%(\mu \mathrm{mol} /$ liter $)$ & $\mu$ mol/liter \\
RGDS & $67.0(50)$ & 8 \\
GRGDS & $52.3(100)$ & 2 \\
RGDSPASSKP & $61.5(100)$ & 24 \\
RGDT & $53.0(100)$ & 6 \\
REDV & $61.4(50)^{*}$ & $>200$ \\
GRADSP & $38.6(50)^{*}$ & 137 \\
RFDS & $55.0(100)$ & $>200$ \\
KGDS & $51.3(100)$ & 80 \\
SDGRG & $59.0(50)$ & $>200$ \\
GQQHHLGGAKQAGDV & $48.3(50)$ & 30 \\
AGDV & $40.2(50)$ & $>200$ \\
\hline
\end{tabular}

Perfusions were performed as described in the legend to Table I with peptides added at concentrations of $10,25,50$, and $100 \mu \mathrm{mol} / \mathrm{liter}$. The platelet adherence observed with each donor's control blood (i.e., without any added peptide) was compared to the corresponding values for experiments with the same donor's blood to which each concentration of peptide had been added to calculate that donor's percent reduction in platelet adherence for each concentration. The percent reductions for all donors were combined for every peptide concentration to yield a mean percent reduction for each peptide at $10,25,50$, and $100 \mu \mathrm{mol} / \mathrm{liter}$. The concentrations in parentheses in the left column represent the concentration in micromoles per liter at which the maximal inhibition of platelet adherence was observed. In other experiments, platelets purified by centrifugation through an arabinogalactan gradient were stimulated with $0.1 \mathrm{U} / \mathrm{ml}$ thrombin (11). vWF purified from normal cryoprecipitate was radiolabeled with ${ }^{125} \mathrm{I}$, and incubated with the platelets in the presence of various concentrations of the indicated peptides (of the same lot numbers as used in the perfusion experiments) for $30 \mathrm{~min}$ at $24^{\circ} \mathrm{C}$ (11). Bound ligand was separated from the free vWF by centrifugation through a $10 \%$ arabinogalactan gradient for $3 \mathrm{~min}$ at $12,000 \mathrm{~g}(11)$, and vWF binding was quantified by $\gamma$-counting. The $\mathrm{IC}_{50}$ represents the concentration of the peptide required to inhibit $50 \%$ of the vWF binding observed in the absence of added peptide $(n=4)$.

* Not tested at $100 \mu \mathrm{mol} / \mathrm{liter}$.

Since in other systems conservative substitutions in the RGD sequence have been shown to cause a loss of peptide inhibitory activity $(6,8-11)$, we used Arg-Gly-Glu-Ser (RGES), Gly-Arg-Ala-Asp-Ser-Pro (GRADSP), and Lys-GlyAsp-Ser (KGDS). We also used Arg-Phe-Asp-Ser (RFDS) and Arg-Glu-Asp-Val (REDV), having selected the latter peptide to examine the effect of two substitutions in the RGDS sequence. In each case, the substituted peptide's capacity to significantly inhibit platelet adherence to subendothelium at the high wall shear rate was retained (Table I). Reversal of the native sequence produced peptides that significantly reduced $S$ and C + S (Table I). In fact, Ser-Asp-Gly-Arg-Gly (SDGRG) showed inhibitory activity nearly equal to that of RGDS (Tables I and II). None of these peptides produced statistically significant changes in platelet thrombi, compared with controls. The maximal inhibition of $\mathrm{C}+\mathrm{S}$ observed in all the experiments was the $67 \%$ reduction produced by $50 \mu \mathrm{mol} / \mathrm{liter}$ RGDS (Table II).

Inhibition of platelet adherence to subendothelium by $f$ brinogen gamma chain carboxyterminal peptides at high wall shear rate $\left(2,600 \mathrm{~s}^{-1}\right)$. The $\mathrm{Fg} \gamma$-chain carboxyterminal pentadecapeptide, GQQHHLGGAKQAGDV, caused inhibition of $\mathrm{S}$ and $\mathrm{C}+\mathrm{S}$ at the high wall shear rate similar to that observed with RGDS (Table I and Fig. 1). Furthermore, like RGDS, GQQHHLGGAKQAGDV also significantly reduced C (Table I). Unlike the situation with fluid-phase adhesive protein binding to platelets $(8,11)$, the terminal tetrapeptide, AGDV, showed inhibitory activity virtually identical to that of the pentadecapeptide (Tables I and II). Similar to the RGD peptides, addition of the $\gamma$-chain peptides to the blood led to unchanged subendothelial coverage with platelet thrombi. Dose-response experiments indicated that, under these experimental conditions, the $\mathrm{Fg} \gamma$-chain peptides are about half as potent as inhibitors of platelet-subendothelial interaction as RGDS.

Inhibition of $v W F$ binding to thrombin-stimulated platelets by $R G D$ - and fibrinogen $\gamma$-chain carboxyterminal peptides. To compare the capacity of the peptides to inhibit platelet-subendothelial interactions with their ability to interfere with vWF binding to thrombin-stimulated platelets, we added various concentrations of the peptides to thrombin-stimulated platelets purified by arabinogalactan centrifugation from normal PRP. vWF was labeled with ${ }^{125} \mathrm{I}$, and after incubation of the platelets with the radiolabeled ligrand, vWF binding was quantitated by $\gamma$ counting. Consistent with the data previously reported by us and others $(8,9,11)$, peptides containing the intact RGD sequence were potent inhibitors of vWF binding, with $\mathrm{IC}_{50}$ values ranging from 2 to $24 \mu \mathrm{mol} / \mathrm{liter}$, similar to their effect on platelet adherence to subendothelium (Tables I and II; Fig. 1). As previously reported $(8,9,11)$, conservative substitutions and amino acid transposition in the RGD sequence led to peptides which were ineffective inhibitors of vWF binding (Table II), despite the fact that the substituted peptides were potent inhibitors of platelet adherence (Tables I and II; Fig. 1). The Fg $\gamma$-chain carboxyterminal pentadecapeptide, GQQHHLGGAKQAGDV, inhibited vWF binding with an $\mathrm{IC}_{50}$ of $30 \mu \mathrm{mol} /$ liter (Table II), consistent with previous reports $(8,11)$. However $A G D V$, which was equipotent with the pentadecapeptide with respect to inhibition of platelet adherence, had no effect on vWF binding to thrombin-stimulated platelets (Table II) $(8,11)$.

Effect of RGD-and Fg $\gamma$-chain carboxyterminal peptides on platelet adherence to subendothelium at low wall shear rate $\left(800 \mathrm{~s}^{-1}\right)$. In perfusions performed at a wall shear rate of 800 $\mathrm{s}^{-1}$, control experiments with citrated whole blood from normal donors gave values for $\mathrm{C}+\mathrm{S}$ of $\sim 45 \%$ (Table III). Compared with the high wall shear rate experiments, at $800 \mathrm{~s}^{-1}$ subendothelial coverage with platelet thrombi was substantially higher, $15.1 \% \pm 3.8 \%$. When RGDS was added to the blood, each parameter of the platelet-subendothelial interaction at $800 \mathrm{~s}^{-1}$ was unchanged, compared with controls (Table III); surface coverage with platelet thrombi was $13.2 \pm 3.9 \%$. The modified RGD peptides KGDS, RGES, and SDGRG also failed to cause statistically significant inhibition of $C+S$ (Table III) or of platelet thrombus formation. The fibrinogen $\gamma$ chain carboxyterminal peptide, GQQHHLGGAKQAGDV, did not alter $\mathrm{C}, \mathrm{S}$, or $\mathrm{C}+\mathrm{S}$, compared with controls (Table III). This peptide did cause a $40 \%$ reduction in mean subendothe- 
Table III. Platelet Adherence to Human Arterial Subendothelium: Effect of Native and Modified Arg-Gly-Asp Peptides and Fibrinogen $\gamma$-Chain Carboxyterminal Peptide at Low Wall Shear Rate $\left(800 \mathrm{~s}^{-1}\right)$

\begin{tabular}{lccc}
\hline \multicolumn{1}{c}{ Peptide ( $n$ ) } & $\begin{array}{c}\text { Contact } \\
\text { (C) }\end{array}$ & Spread (S) & $\begin{array}{c}\text { Total platelet } \\
\text { adherence (C + S) }\end{array}$ \\
& $\%$ & $\%$ & \\
Controls (11) & $0.9 \pm 0.1$ & $43.0 \pm 3.1$ & $43.9 \pm 3.1$ \\
RGDS (7) & $0.6 \pm 0.1$ & $42.1 \pm 2.9$ & $42.8 \pm 2.8$ \\
KGDS (3) & $0.8 \pm 0.1$ & $39.6 \pm 7.1$ & $40.4 \pm 7.1$ \\
RGES (4) & $0.6 \pm 0.1$ & $32.2 \pm 3.7$ & $32.8 \pm 3.6$ \\
SDGRG (5) & $0.6 \pm 0.1$ & $31.2 \pm 6.4$ & $32.2 \pm 6.5$ \\
GQQHHLGGAKQAGDV (5) & $0.7 \pm 0.2$ & $41.3 \pm 3.5$ & $41.9 \pm 3.5$
\end{tabular}

Segments of de-endothelialized human umbilical artery subendothelium were perfused with citrated whole blood from six normal donors in an annular perfusion chamber at $37^{\circ} \mathrm{C}$ for $5 \mathrm{~min}$ (wall shear rate $=800 \mathrm{~s}^{-1}$ ) as described in the legend to Table $\mathrm{I}$. None of the values was statistically significantly different from control values.

lial coverage with platelet thrombi $(8.9 \pm 3.0 \%)$, compared with controls, but this failed to achieve statistical significance $(P$ $>0.30$ ).

Effect of RGD-and Fg $\gamma$-chain carboxyterminal peptides on static platelet adhesion to collagen. In view of the profound differences in the effect of RGD- and Fg $\gamma$-chain peptides on platelet adherence to subendothelium observed between experiments performed at high and low wall shear rates, studies were performed in a nonflowing adhesion system. Native or substituted RGD peptides were added to platelets labeled with [ ${ }^{111}$ In]oxyquinoline, and platelet adhesion to type I collagen immobilized in microtiter wells was measured. In contrast to previously reported studies involving platelet adhesion to immobilized vWF, Fg, or Fn (9), RGDS did not inhibit this static platelet adhesion. Furthermore, none of the modified RGD peptides studied (RGDT, RGES, KGDS, or SDGRG) had any significant effect on platelet adhesion to immobilized collagen. The Fg $\gamma$-chain carboxyterminal peptide, GQQHHL-GGAKQAGDV, also failed to inhibit static platelet adhesion to collagen.

\section{Discussion}

It is well established that GP IIb-IIIa contains the receptor site(s) that mediate(s) the binding of $\mathrm{Fg}, \mathrm{Fn}, \mathrm{Vn}$, and vWF to thrombin-stimulated platelets $(10,24-27)$. vWF and Fn binding to GP IIb-IIIa is necessary for optimal platelet spreading and adhesion to artificial adhesive protein substrates in static systems (9), and these proteins are required for normal platelet adherence to subendothelium with flowing blood (15-18). Dedhar et al. (28) have recently demonstrated that the RGD sequence in collagen type $I$ is essential for recognition by the collagen receptor present in osteosarcoma cells (28). RGDand $\mathrm{Fg} \gamma$-chain peptides have been shown to inhibit $\mathrm{Fg}, \mathrm{Fn}$, $\mathrm{Vn}$, and vWF binding to platelets (Table II) $(6-13,27)$, and platelet adhesion to subendothelium at high wall shear rates (29), and the former peptides reduced platelet adhesion to $\mathrm{Fg}$, Fn, and vWF substrates in a nonflowing assay system (9).

We sought to determine whether these peptides would show similar specificity and effects on platelet adherence to human arterial subendothelium under the conditions of high wall shear physiologically present in the microvasculature (20). At 2,600 s $\mathrm{s}^{-1}$, our experiments demonstrated significant dosedependent inhibition in platelet adherence with RGDS and GQQHHLGGAKQAGDV (Tables I and II; Fig. 1), confirming the results of previous studies (29). The reduction in subendothelial coverage with spread platelets (S) was the predominant finding (Table I and Fig. 1). S, measured at a single point in time, reflects a complex interaction between the rate of initial platelet attachment to the surface and the rate at which these attached platelets spread along the subendothelium (30). Thus, our morphometric observations may reflect interference by RGDS and GQQHHLGGAKQAGDV with platelet contact, spreading, or both. The maximal reductions of platelet adherence $(C+S)$ observed with RGDS $(67 \%)$ and GQQHHLGGAKQAGDV (55\%) were quite similar to the reductions we found in an earlier study with the anti-GP IIb-IIIa monoclonal antibodies 10E5 (53\%) and PLT-1 (62\%) (15). This suggests that, under the high wall shear perfusion conditions employed, $\sim 55-65 \%$ of the observed platelet adherence is dependent upon GP IIb-IIIa. This is probably the maximal contribution of GP IIb-IIIa, since use of GRGDS in concentrations of 150 and $250 \mu \mathrm{mol} / \mathrm{liter}$ failed to cause a further diminution in $\mathrm{C}+\mathrm{S}$ beyond that seen with $50 \mu \mathrm{mol} / \mathrm{liter}$ RGDS.

Although vWF, Fn, Fg, and GP IIb-IIIa are known to be important in platelet-platelet interactions, little is understood about the nature of the association between vWF, Fn, and GP IIb-IIIa involved in platelet adherence in a flowing system. The interaction of Fg or Fn with GP IIb-IIIa does not appear to be important for platelet adherence $(29,31)$. However, recent evidence suggests that binding of vWF to GP IIb-IIIa does play a significant role in platelet adherence and subendothelial thrombus formation $(29,32)$. Since amino acid modification in RGD peptides leads to loss of inhibitory activity with respect to platelet adhesive protein binding (Table II) $(6,8-11)$ and static platelet adhesion (9), and the terminal tetrapeptide of GQQHHLGGAKQAGDV also fails to interfere with adhesive protein binding (Table II) $(8,11)$, we used modified peptides to examine further the correspondence between standard fluid-phase binding assays and our flowing adhesion system. The presumed mechanism for the contribution of GP IIb-IIIa to platelet adherence involves the binding of subendothelialassociated vWF to the previously described relevant epitope(s) on GP IIb-IIIa. Therefore, it is surprising that RGES, GRADSP, RFDS, KGDS, SDGR, SDGRG, REDV, and AGDV were effective inhibitors of platelet adherence in our experiments performed at a wall shear rate of $2,600 \mathrm{~s}^{-1}$ (Tables I and II). This inhibition does not appear to be a nonspecific effect of the addition of the peptides, for the control peptides VGSE, LG, and MFM had no effect on platelet adherence (Table I). The recent observation of Raha et al. (33) that the peptide KRDS inhibits Fg binding to platelets and platelet aggregation is of interest, since this peptide represents a sequence similar to some of the peptides (e.g., KGDS) that were inhibitory in our high shear rate experiments but inactive in previous fluid-phase and static platelet adhesion studies.

Yamada and Kennedy (34) recently reported that the reverse tetrapeptide, SDGR, was capable of inhibiting fibroblast adhesion and spreading on a Fn substrate. The VLA-5 Fn receptor on platelets (glycoprotein Ic-IIa) is apparently identical to the protein found on fibroblasts (35). Thus, while Fn 
interaction with GP IIb-IIIa is not likely to be involved (31), our observation that SDGR (and SDGRG) significantly inhibited platelet adherence to subendothelium at 2,600 s $\mathrm{s}^{-1}$ (Table I) provides indirect evidence that VLA-5 may play a role in platelet adherence to subendothelium at high wall shear rates. Our data suggest that the recognition site(s) on the platelet membrane involved at high wall shear rates in platelet adherence to the biochemically heterogenous surface of arterial subendothelium differs significantly in specificity from those that mediate $\mathrm{Fg}, \mathrm{Fn}$, and vWF binding to stimulated platelets in the fluid phase or in a static assay system. The specificity of such recognition sites may be shared in part between platelets and fibroblasts (34).

Our studies of platelet adherence to subendothelium at a wall shear rate of $800 \mathrm{~s}^{-1}$ demonstrated a significant shear rate dependence of the effects of RGD- and Fg $\gamma$-chain peptides (Table III). Not only were the modified peptides without significant inhibitory effects on the platelet-subendothelial interaction, but even RGDS and GQQHHLGGAKQAGDV failed to alter platelet adherence (Table III). Nievelstein and Sixma (31) demonstrated that GRGDSP and GRGESP at $1 \mathrm{mmol} /$ liter have no effect on platelet adhesion to endothelial cell matrix at $1,500 \mathrm{~s}^{-1}$. These authors did not perform studies at shear rates $>1,500 \mathrm{~s}^{-1}(31)$. Weiss et al. (29) recently reported that RGDS significantly inhibited platelet adhesion to rabbit arterial subendothelium at $2,600 \mathrm{~s}^{-1}$. These authors stated that the inhibitory effect of RGDS was consistently less in perfusions performed at $800 \mathrm{~s}^{-1}$ than at the higher wall shear rate, although they did observe significant inhibition at $800 \mathrm{~s}^{-1}$ (C $+\mathrm{S}=71 \pm 9 \%$ of control values; $P<0.05$ ) (31). Weiss and colleagues (31) employed whole-blood concentrations of RGDS which were 10 -fold or more higher (500 $\mu \mathrm{mol} / \mathrm{liter})$ than those used in the present study; by contrast, at $2,600 \mathrm{~s}^{-1}$ we found significant inhibition of platelet adherence to human arterial subendothelium at a concentration of $25 \mu \mathrm{mol} / \mathrm{liter}$ (Fig. 1). Thus, the RGD recognition specificities that govern platelet adherence to subendothelium appear to be profoundly shear rate-dependent. The discrepancy between the effects of RGD peptides on human (and rabbit) arterial subendothelium and those observed on endothelial cell matrix (30) may reflect either the difference in wall shear rates employed $(2,600$ vs. $1,500 \mathrm{~s}^{-1}$ ) or, more likely, the disparity between the matrix produced by a single population of cells in culture and the biochemically and histologically complex vascular wall formed in vivo by multiple cell types.

The experiments we performed to examine static platelet adhesion to collagen type I provide further evidence for sheardependent differences in platelet-surface interactions. Neither RGDS nor GQQHHLGGAKQAGDV significantly impaired platelet adhesion to collagen, and GRGDSP, RGDT, RGES, KGDS, and SDGRG failed to significantly affect the plateletcollagen interaction. Nievelstein and Sixma (31) failed to observe significant inhibition of platelet adhesion to collagen type $I$ in low shear rate perfusions ( 300 and $800 \mathrm{~s}^{-1}$ ), whereas at $1,500 \mathrm{~s}^{-1}$ they reported significant inhibition by GRGDSP, but not by GRGESP. The collagen type I surface appears to differ from Fg, Fn, and vWF substrates, in that static platelet adhesion to the latter surfaces is impaired by intact, but not modified, RGD peptides (9), whereas platelet adhesion to collagen is unaffected. Our findings, in conjunction with those of Nievelstein and Sixma (31), suggest that the mechanisms which govern platelet adhesion to collagen at shear rates at or below
$800 \mathrm{~s}^{-1}$ (including static, nonflowing conditions) are distinct from those operative at higher shear rates. Platelet adherence to vascular subendothelium and to collagen appear to be similar in their shear dependence.

In addition to GP IIb-IIIa, platelets contain the adhesive protein receptors, or integrins, VLA-2 (glycoprotein Ia-IIa complex) and VLA-5 (the latter receptor apparently represents the glycoprotein Ic-IIa complex [36]) $(5,35-43)$. VLA-2 is a collagen receptor $(37,38,41,43)$, and deficiency of this protein in a patient has been associated with clinical bleeding and profoundly impaired platelet adherence to collagen and human arterial subendothelium $(39,40)$. VLA- 5 constitutes a Fn receptor $(35,42)$. GP IIb-IIIa and VLA-5 recognize the RGD sequence (5). Thus, it may be that the substituted, transposed, or truncated peptides used in the present study interfered with the binding of subendothelial-associated adhesive proteins to one or more of these receptors, leading to inhibited platelet adherence at the high wall shear rate. In their recent report, Nievelstein and Sixma (31) have presented platelet adhesion data which strongly support the existence of a second platelet binding site for Fn, distinct from GP IIb-IIIa, which appears to be important for platelet adherence at high wall shear rates (31). We have observed significant inhibition of platelet adherence to subendothelium with a murine monoclonal antibody directed against VLA-2 (41). It would therefore appear likely that other integrins in addition to GP IIb-IIIa contribute to platelet-subendothelial interactions under conditions of high wall shear.

It is also possible that the modified peptides may interfere at high wall shear rates with the binding to GP IIb-IIIa (or VLA-2 or VLA-5) of subendothelial adhesive proteins other than Fn or vWF, such as Vn. Recent evidence suggests that Vn plays a role in platelet aggregation (27), and it may also contribute to platelet adherence. However, while GRGDSP was demonstrated by Thiagarajan and Kelly (10) to inhibit Vn binding to platelets, GRGESP was ineffective. The effects of other substituted or transposed RGD peptides on Vn binding to platelets have not been reported, to our knowledge.

A plausible mechanism suggested by our present data and other recent studies is that the adherence of platelets to vascular subendothelium is governed by the following receptor-surface ligand interactions: ( $a$ ) GP Ib-vWF, (b) GP IIb-IIIa-vWF, (c) GP IIb-IIIa-Vn, (d) VLA-2-collagen, and (e) VLA-5-Fn. At low wall shear rates, addition of RGD- or $\mathrm{Fg} \gamma$-chain carboxyterminal peptides may interfere with the binding of subendothelial-associated vWF, collagen, Fn, and/or Vn to GP IIb-IIIa, VLA-2 and VLA-5, and still the GP Ib-vWF interaction may be sufficient to support normal platelet adherence. In patients deficient in vWF, the interaction between integrin receptor(s) and non-vWF adhesive proteins (i.e., collagen, Fn, and/or Vn) may be adequate to support platelet adherence, accounting for the normal platelet adherence at low wall shear rates observed in patients with von Willebrand's disease. However deficiency, or monoclonal antibody blockade, of GP Ib or GP IIb-IIIa leads to impaired platelet adherence at low wall shear rates (16). In the case of static platelet adhesion to a collagen substrate in a purified system devoid of $\mathrm{vWF}$, the relevant platelet collagen receptor (e.g., VLA-2) may behave similarly to collagen receptors on other cell types which support adhesion to collagen in the presence of RGDS, but not when exposed to peptides such as GRGDTP which are conformationally more suitable to interfere with the receptor-li- 
gand interaction $(28,44,45)$. By contrast, at high wall shear rates, $\mathrm{RGD}$ - or $\mathrm{Fg} \gamma$-chain peptides may inhibit one or more of the integrin-receptor interactions in $b-e$ described above, and the GP Ib-vWF interaction is inadequate to support normal platelet spreading along the subendothelium $(15,16)$ (Tables I and II; Fig. 1).

Alternatively, each amino acid in the RGD sequence of the subendothelial-associated adhesive protein may be required for platelets subjected to high wall shear to remain attached via the relevant integrin. Exposure of the receptor to peptides in which one of the RGD amino acids is substituted may interfere with the integrin-adhesive protein bond via the nonsubstituted residues. This effect on the receptor may be sufficient to weaken the platelet-subendothelial bond so that platelet adherence is impaired. By contrast, in nonflowing systems, the effect of a substituted peptide to prohibit the binding of one or two of the adhesive protein RGD residues to the integrin may fail to interfere with the overall receptor-ligand association, because the nonblocked residues in the protein may be adequate to maintain the platelet-protein attachment when shear stress is absent. This proposed mechanism implies several testable hypotheses. Future experiments utilizing monoclonal antibodies specific for the various platelet integrins, singly and in combination, reconstituted perfusates deficient in one or more plasma adhesive proteins, and monoclonal antibody treatment of the subendothelial surface should provide much additional insight concerning the shear-dependent receptor-ligand associations important for platelet adherence to subendothelium.

\section{Acknowledgments}

We thank Ms. Sharon L. Bodenheimer and Mrs. Linda C. Burke for excellent technical and secretarial assistance, respectively.

\section{References}

1. Doolittle, R. F., K. W. K. Watt, B. A. Cottrell, D. D. Strong, and M. Riley. 1979. The amino acid sequence of the $\alpha$-chain of human fibrinogen. Nature (Lond.). 280:464-468.

2. Pierschbacher, M. D., and E. Ruoslahti. 1984. Variants of the cell recognition site of fibronectin that retain attachment-promoting activity. Proc. Natl. Acad. Sci. USA. 81:5985-5988.

3. Sadler, J. E., B. B. Shelton-Inloes, J. M. Sorace, J. M. Harlan, K. Titani, and E. W. Davie. 1984. Cloning and characterization of two cDNAs coding for human von Willebrand factor. Proc. Natl. Acad. Sci. USA. 82:6394-6398.

4. Suzuki, S., A. Oldberg, E. G. Hayman, M. D. Pierschbacher, and E. Ruoslahti. 1985. Complete amino acid sequence of human vitronectin deduced from cDNA: similarity of cell attachment sites in vitronectin and fibronectin. EMBO (Eur. Mol. Biol. Organ.) J. 4:25192524.

5. Ruoslahti, E., and M. D. Pierschbacher. 1987. New perspectives in cell adhesion: RGD and integrins. Science (Wash. DC). 238:491496.

6. Ginsberg, M., M. D. Pierschbacher, E. Ruoslahti, G. Marguerie, and E. Plow. 1985. Inhibition of fibronectin binding to platelets by proteolytic fragments and synthetic peptides which support fibroblast adhesion. J. Biol. Chem. 260:3931-3936.

7. Gartner, T. K., and J. S. Bennett. 1985. The tetrapeptide analogue of the cell attachment site of fibronectin inhibits platelet aggregation and fibrinogen binding to activated platelets. J. Biol. Chem. 260:11891-11894.

8. Plow, E. F., M. D. Pierschbacher, E. Ruoslahti, G. A. Marguerie, and M. H. Ginsberg. 1985. The effect of Arg-Gly-Asp-containing peptides on fibrinogen and von Willebrand factor binding to platelets. Proc. Natl. Acad. Sci. USA. 82:8057-8061.

9. Haverstick, D. M., J. F. Cowan, K. M. Yamada, and S. A. Santoro. 1985. Inhibition of platelet adhesion to fibronectin, fibrinogen, and von Willebrand factor substrates by a synthetic tetrapeptide derived from the cell-binding domain of fibronectin. Blood. 66:946952.

10. Thiagarajan, P., and K. Kelly. 1988. Exposure of binding sites for vitronectin on platelets following stimulation. J. Biol. Chem. 263:3035-3038.

11. Williams, S., and H. Gralnick. 1987. Inhibition of von Willebrand factor binding to platelets by two recognition site peptides: the pentadecapeptide of the carboxy terminus of the fibrinogen gamma chain and the tetrapeptide Arg-Gly-Asp-Ser. Thromb. Res. 46:457471.

12. Kloczewiak, M., S. Timmons, T. J. Lukas, and J. Hawiger. 1984. Platelet receptor site recognition on human fibrinogen: synthesis and structure-function relationship of peptides corresponding to the carboxy-terminal segment of the $X$ chain. Biochemistry. 23:17671774.

13. Plow, E. F., A. H. Srouji, D. Meyer, G. Marguerie, and M. H. Ginsberg. 1984. Evidence that three adhesive proteins interact with a common recognition site on activated platelets. J. Biol. Chem. 259:5388-5391.

14. Parise, L. V., S. L. Helgerson, B. Steiner, L. Nannizzi, and D. R. Phillips. 1987. Synthetic peptides derived from fibrinogen and fibronectin change the conformation of purified platelet glycoprotein IIbIIIa. J. Biol. Chem. 262:12597-12602.

15. Lawrence, J. B., and H. R. Gralnick. 1987. Monoclonal antibodies to the glycoprotein IIb-IIIa epitopes involved in adhesive protein binding: effects on platelet spreading and ultrastructure on human arterial subendothelium. J. Lab. Clin. Med. 109:495-503.

16. Weiss, H. J., V. T. Turitto, and H. R. Baumgartner. 1986. Platelet adhesion and thrombus formation on subendothelium in platelets deficient in glycoproteins IIb-IIIa, Ib, and storage granules. Blood. 67:322-330.

17. Sakariassen, K. S., P. A. Bolhuis, and J. J. Sixma. 1979. Human blood platelet adhesion to artery subendothelium is mediated by Factor VIII-von Willebrand factor bound to the subendothelium. Nature (Lond.). 279:636-638.

18. Houdijk, W. P. M., and J. J. Sixma. 1985. Fibronectin in artery subendothelium is important for platelet adhesion. Blood. 65:598604.

19. Baumgartner, H. R., and R. Muggli. 1976. Adhesion and aggregation: Morphological demonstration and quantitation in vivo and in vitro. In Platelets in Biology and Pathology. J. L. Gordon, editor. Elsevier/North-Holland, Amsterdam. 23-60.

20. Turitto, V. T., and H. R. Baumgartner. 1979. Platelet interaction with subendothelium in flowing rabbit blood: effect of blood shear rate. Microvasc. Res. 17:38-54.

21. Turitto, V. T., and H. R. Baumgartner. 1987. Platelet-surface interactions. In Hemostasis and Thrombosis. Basic Principles and Clinical Practice. R. W. Colman, J. Hirsh, V. J. Marder, and E. W. Salzman, editors. J. B. Lippincott Co., Philadelphia. 555-571.

22. Brown, B. W., and M. Hollander. 1977. Statistics-A Biomedical Introduction. John Wiley \& Sons, Inc., New York. 85-108.

23. Kessler, C. M., C. M. Floyd, M. E. Rick, D. M. Krizek, S. L. Lee, and H. R. Gralnick. 1984. Collagen-Factor VIII/von Willebrand factor protein interaction. Blood. 63:1291-1298.

24. Bennett, J. S., and G. Vilaire. 1979. Exposure of platelet fibrinogen receptors by ADP and epinephrine. J. Clin. Invest. 64:13931398.

25. Ginsberg, M. H., J. Forsyth, A. Lightsey, J. Chediak, and E. F. Plow. 1983. Reduced surface expression and binding of fibronectin by thrombin-stimulated thrombasthenic platelets. J. Clin. Invest. 71:619-624.

26. Ruggeri, Z. M., R. Bader, and L. De Marco. 1982. Glanz- 
mann's thrombasthenia: Deficient binding of von Willebrand factor to thrombin-stimulated platelets. Proc. Natl. Acad. Sci. USA. 79:60386041.

27. Asch, E., and E. R. Podack. 1987. Vitronectin binds to activated platelets and plays a role in platelet aggregation. Blood. 70(Suppl. I):346a. (Abstr.)

28. Dedhar, S., E. Ruoslahti, and M. D. Pierschbacher. 1987. A cell surgace receptor complex for collagen type I recognizes the Arg-GlyAsp sequence. J. Cell Biol. 104:585-593.

29. Weiss, H. J., J. Hawiger, Z. M. Ruggeri, V. T. Turitto, P. Thiagarajan, and T. Hoffman. 1989. Fibrinogen-independent platelet adhesion and thrombus formation on subendothelium mediated by glycoprotein IIb-IIIa complex at high wall shear rate. J. Clin. Invest. 83:288-297.

30. Turitto, V. T., H. J. Weiss, and H. R. Baumgartner. 1983. Decreased platelet adhesion on vessel segments in von Willebrand's disease: a defect in initial platelet attachment. J. Lab. Clin. Med. 102:551-564.

31. Nievelstein, P. F. E. M., and J. J. Sixma. 1988. Glycoprotein IIb-IIIa and RGD(S) are not important for fibronectin-dependent platelet adhesion under flow conditions. Blood. 72:82-88.

32. Fressinaud, E., D. Baruch, J. P., Girma, K. S. Sakariassen, H. R. Baumgartner, and D. Meyer, 1988. von Willebrand factor-mediated platelet adhesion to collagen involves platelet membrane glycoprotein IIb-IIIa as well as glycoprotein Ib. J. Lab. Clin. Med. 112:5867.

33. Raha, S., C. Dosquet, J. F. Abgrall, P. Jolles, A. M. Fiat, and J. P. Caen. 1988. KRDS-A tetrapeptide derived from lactoferrin-inhibits binding of monoclonal antibody against glycoprotein IIb-IIIa on ADP-stimulated platelets and megakaryocytes. Blood. 72:172-178.

34. Yamada, K. M., and D. W. Kennedy. 1985. Amino acid sequence specificities of an adhesive recognition signal. J. Cell. Biochem. 28:99-104.

35. Piotrowicz, R. S., R. P. Orchekowski, D. J. Nugent, K. Y. Yamada, and T. J. Kunicki. 1988. Glycoprotein Ic-Ila functions as an activation-independent fibronectin receptor on human platelets. $J$. Cell. Biol., 106:1359-1364.
36. Hemler, M. E., C. Crouse, Y. Takada, and A. Sonnenberg. 1988. Multiple Very Late Antigen (VLA) heterodimers on platelets: evidence for distinct VLA-2, VLA-5 (fibronectin receptor), and VLA-6 structures. J. Biol. Chem. 263:7660-7665.

37. Pischel, K. D., M. E. Hemler, C. Huang, H. G. Bluestein, and V. L. Woods. 1987. Use of the monoclonal antibody $12 \mathrm{~F} 1$ to characterize the differentiation antigen VLA-2. J. Immunol. 138:226-233.

38. Pischel, K. D., H. G. Bluestein, and V. L. Woods. 1988. Platelet glycoproteins Ia, Ic, and IIa are physicochemically indistinguishable from the very late activation antigens adhesion-related proteins of lymphocytes and other cell types. J. Clin. Invest. 81:503-513.

39. Nieuwenhuis, H. K., H. W. N. Akkerman, W. P. M. Houdijk, and J. J. Sixma. 1985. Human blood platelets showing no response to collagen fail to express surface glycoprotein Ia. Nature (Lond.). 318:470-472.

40. Nieuwenhuis, H. K., K. S. Sakariassen, W. P. M. Houdijk, P. F. E. M. Nievelstein, and J. J. Sixma. 1986. Deficiency of platelet membrane glycoprotein Ia associated with a decreased platelet adhesion to subendothelium: a defect in platelet spreading. Blood. 68:692-695.

41. Gralnick, H. R., L. P. McKeown, S. B. Williams, J. B. Lawrence, B. C. Shafer, W. S. Kramer, K. E. Hansmann, M. L. Vail, and L. E. Magruder. 1988. A murine monoclonal antibody that identifies a $157 / 130 \mathrm{kDa}$ platelet-collagen receptor. Circulation. 78(Suppl. II):308. (Abstr.)

42. Takada, Y., C. Huang, and M. E. Hemler. 1987. Fibronectin receptor structures in the VLA family of heterodimers. Nature (Lond.). 326:607-609.

43. Staatz, W. D., S. M. Rajpara, E. A. Wayner, W. G. Carter, and S. A. Santoro. 1989. The membrane glycoprotein Ia-IIa (VLA-2) complex mediates the $\mathbf{M g}^{++}$-dependent adhesion of platelets to collagen. $J$. Cell Biol. 108:1917-1924.

44. Hayman, E. G., M. D. Pierschbacher, and E. Ruoslahti. 1985. Detachment of cells from culture substrate by soluble fibronectin peptides. J. Cell Biol. 100:1948-1954.

45. Pierschbacher, M. D., and E. Ruoslahti. 1987. Influence of stereochemistry on the sequence Arg-Gly-Asp-Xaa on binding specificity in cell adhesion. J. Biol. Chem. 262:17294-17298. 